\title{
Ideological trends in initial teacher education curricula: the case of East African universities
}

\author{
Proscovia Namubiru Ssentamu
}

\begin{abstract}
This paper reviews the ideological trends in initial teacher education curricula in East African universities during the post-independent and contemporary times. From the mid-1960s and mid-1980s, initial teacher education curricula were integrated and harmonised with support from the East African Community whose efforts were coordinated by the Inter-University Council for East Africa. With the breakup of the Community in 1977, each independent state pursued its own educational strategy. However, underfunding of the public sector by governments, introduction of market-friendly reforms under the World Bank Structural Adjustment Programme in 1987 and the de-regularisation policies led to the liberalisation of public services, including education. Liberalisation affected among others, the quality of the initial teacher education curricula. Consequently, national councils and commissions for higher education were established to control standards in higher education, and the Inter-University Council for East Africa was revived to standardise and harmonise educational standards at regional level. The review shows that over the past five decades, the structure and organisation of initial teacher education curricula has continuously adjusted itself and been adjusted to a hybrid culture blending classical humanism, utilitarianism, social re-constructionism, market and global ideologies. Comparable ideological inclinations at socio-economic and political levels have influenced this trend in the region. The paper highlights the implications of such trends on the future of initial teacher education in the region.
\end{abstract}

Keywords: Ideology; post-independent; liberalisation; initial teacher education; higher education; curriculum; East African Community.

\section{Introduction}

The three traditional East African countries i.e. Kenya, Tanzania and Uganda that were formally British colonies constitute the geographical scope of this paper. Although with the revivification of the East African Community, Rwanda and Burundi joined in 2007, since these were formally French colonies, and therefore have a different historical background, they are beyond the scope of the current review. The paper restricts itself to the undergraduate teacher education curriculum, also commonly referred to as pre-service or initial teacher education. The term 'curriculum' is defined 
variously, however, in this paper; focus is on the initial teacher education structure and organisation.

It is true that teacher preparation has become a controversial issue, perhaps more than ever before, especially regarding how much formal teacher preparation is required and how it should be delivered. ${ }^{1}$ However, because of various contextual challenges, there are more questions posed in Sub-Saharan Africa than perhaps elsewhere regarding the quality of education at various levels. As Stuart and Tatto $^{2}$ posit, it is important to understand the historical, socio-economic and cultural contexts in which initial teacher education programmes emerge, and the political and epistemological tensions that may arise.

The development of education in East Africa has been continually shaped by its history as a former British colony ${ }^{3}$, but also by motivational forces at domestic, continental and global levels. This review aims to reflect on current thinking about initial teacher education by reviewing the historical and contemporary ideologies informing initial teacher education curricula within the East African universities. For ease of the review, the postindependent period runs between the mid-1960s and mid-1980s, while the contemporary period starts from the mid-1980s to date.

The post-independent period describes the struggles East Africa experienced as she transitioned from political dependence to sovereignty. The mid 1980s to date are contemporary years in which East Africa has continually endeavoured to adjust to domestic, continental and global forces. These two eras are characterised by diversity in the structure and organisation of initial teacher education curricula. The aim of the paper is to review the ideological trends in the initial teacher education curricula in the East African universities in order to interrogate the implications of such trends in the development of future initial teacher education curricula within the region. Specifically, the review focuses on two major questions, that is:

a) What was the structure and organisation of initial teacher education in East Africa during the post-independent period (mid 1960s and mid 1980s)?

b) What is the structure and organisation of initial teacher education in East Africa in contemporary times (mid 1980s to date)?

1 John Schwille and Martial Dembélé, Global perspectives on teacher learning: Improving policy and practice (Paris: UNESCO International Institute for Educational Planning, 2007).

2 Janet S. Stuart and Maria Teresa Tatto, "Designs for initial teacher preparation programs: An international review," International Journal of Educational Research 33 (2000): 493.

${ }^{3}$ Refer also to Damtew Teferra and Philip, G. Altbach, Higher Education (2014), 24. 
The first half of the paper describes the methodology used to sample, collect and analyse the literature. Thereafter, ideologies in education and the historical development of formal higher education in East Africa are briefly reviewed. In the final half of the paper, the structure and organisation of initial teacher education in East Africa during the two periods are reviewed reflecting the challenges and opportunities presented. A conclusion and implications with regard to the study findings are made.

\section{Methodology}

Reviews of various literature ${ }^{4}$ formed the bulk of this paper, i.e. reports and literature from the national councils or commissions for higher education in Kenya, Tanzania and Uganda, the Inter-University Council of East Africa (IUCEA), purposely sampled literature from within and beyond the region, UNESCO reports on teacher quality, and dissertations. Findings from the reviewed literature were categorised, analysed and discussed based on the study's key research questions. Patterns and relationships in the information were identified to appreciate unique cases and draw generalisations regarding initial teacher education developments within the region in light of the wider social context.

${ }^{4}$ Literature reviewed included: Yoweri K. Bamanyaki, Unpublished M.Ed. Dissertation of Makerere University, (1979); Sorobea N. Bongoko, A history of modern education in Kenya (18951991), (1992); Friedrich Buchberger, Campos, P. Bártolo, Daniel Kallos, and John Stephenson, Eds., Green paper on teacher education in Europe: High quality teacher education for high quality education and training, (Thematic Network for Teacher Education in Europe (2000); Bonny Busingye, Unpublished M.Ed. Dissertation of Makerere University (1989), Eastern \& South African Universities Research Program, University capacity in Eastern and Southern African Countries (1987); Inter-University Council for East Africa, Jumuiya ya Afrika Mashariki, East African Business Council, Regional higher education qualifications gaps versus the region's human resources needs: Finding EAC Higher Education Competence Sweet Spot, Situation composite EAC Report, Unpublished, Vol. II, (2014); Abel G.M. Ishumi, Africa Education Review, (10(1): 89-116, 2014); Festus Kaberia, Joyce M. Mutinda, Margaret K. Kobia, Higher Education: Cross-border higher education: regulation, quality assurance and impact, (International Institute for Educational Planning, Vol. II, UNESCO, 2007); Xiaoyan Liang, Uganda Tertiary Education Sector, Africa Region Human Resource Development, (Working Paper Series, World Bank: Africa Region, 2004); Samuel E. Lugumba and John C. Ssekamwa, A History of Education in East Africa (1900-1973); Makerere University College of Education and External Studies Strategic Plan (2011/12-2018/19) (2011); Daniel W. Nabudere, Southern African Review of Education, A Journal of Comparative Education and History of Education, (13(2) 125-138, 2007); Uganda National Council for Higher Education Reports (2004, 2006, 2007, 2012); University of Dar es Salaam Undergraduate programs and administration procedure, (2007) and Prospectus (1990); Uganda Government, White Paper on Education (1992); 'and references therein'. 


\section{Ideologies and Education}

Ideology as a system of belief, generalisations and social practices is related to what it does in naturalising certain attitudes and ways of thinking, and in legitimising existing power relations. The existing powers legitimise these ideologies as policy directing an education system. Consequently, policy statements are translated into the curriculum and eventually into society. This genre of official documents and policy statements has a shaping effect on practices within institutions and the wider society as manifest in guidelines, standards, social expectations and cultural values..$^{5}$

Classical humanism as a value system focuses on the transmission of knowledge and cultural values from generation to generation. Indeed, values were passed on from the colonial to the post-colonial era. Post-colonialism refers to the political and theoretical struggles of countries as they transition from external political dependence to sovereignty. In the case of East Africa, post-colonialism was the period after the national liberation struggles in the early 1960 s that led to political independence. In relation to colonial and post-colonial history, classical humanism endorses academic rationalism, ${ }^{6}$ since it concerns itself with students' intellectual development and acquisition of knowledge associated with the established academic disciplines. Therefore, the role of a university is to transmit, create and classify knowledge through teaching, research and publication.

A theory closely related to classical humanism is essentialism, which suggests that certain basic ideas, disciplines and skills essential to culture should be taught to all students using certain time-tested methods. The goals of education are primarily cognitive and intellectual, aimed to preserve and transmit cultural heritage in the various subject disciplines. Therefore, an academic teacher education curriculum focuses on cultivating high levels of academic knowledge, skills and values among students. The best student is one who correctly reproduces the transmitted knowledge, skills and values. Like essentialists, classical humanists seek to preserve the ideals of society and adjust the populace to fit into their thinking.

Utilitarianism or social and economic efficiency is another ideology influencing education. With its generally economic undertone and pragmatic view, the role of educational institutions is to prepare prospective teachers with the competences they will require for their working lives in schools, and satisfy societal needs. Although utilitarianism has ethical connotations under

5 Judy Woon Ye Ho, Language and Education (2002).

${ }^{6}$ Paul Morris (1995) cited in Judy, Woon, Ye Ho, Language and Education (2002). 
the 'the greatest happiness of the greatest number'7 description, which foretell inclusion and equity in accessibility of services, it is criticised for its emphasis on quantity relegating value concerns. This ideology also emphasises the power of an individual and his or her potential for the consumption of goods and services.

A related value system sharing the maximisation of good consequences is social re-constructionism, which holds that in promoting what is educationally desirable in a given context, educational institutions are powerful instruments in developing prospective teachers' abilities to improve and cause social and cultural change. In this value system, equality, tolerance and acceptance of diversity are treasured democratic ideals. ${ }^{8}$ It is no surprise then that in post-independent countries, education was considered a powerful tool in reconstructing society through nation building and national integration. In order to address concerns such as nation building and national integration, curricula and pedagogy has to be tailored to respond to the immediate needs and aspirations of a given society. Unlike classicists and essentialists, social re-constructionists seek to change society and adjust it to contemporary conditions, implying a flexible and multidisciplinary curriculum. In this instance, faculties or schools of education and teacher educators are principal agencies and agents of change, respectively.

This review also acknowledges the influence of market and global ideologies on initial teacher education. There are two types of markets considered in this review; i.e. the academic study market, which provides a range of differentiated study programmes from which students make a choice, and the labour market, which absorbs graduate teachers. In both markets, quality, quantity and competition are important words. Due to its liberal nature, the labour market ideology emphasises individual rights and equality of opportunities. Since the market is vibrant, there is a continual adjustment of existing values and social practices for the good of society. With the advent of globalisation, the market extended its frontiers from the national to regional and finally to global boundaries. However, sometimes the sequence did not matter. Consequently, universities had to address issues emerging from general macro socio-economic policy reforms; that is, competitive policy reforms, financing policy reforms and equity policy reforms. ${ }^{9}$ These reforms are reflected in the utilitarian and social reconstructionist ideologies.

7 Webster $3^{\text {rd }}$ New International Dictionary of the English Language, 2525.

${ }^{8}$ Paul Morris (1995) cited in Judy Won Ye Ho, Language and Education (2002).

9 Martin Carnoy cited in DIES $1113^{\text {rd }}$ Dialogue on Innovative Higher Education Strategies $(2003,38)$. 
The ideologies highlighted above move along a continuum; i.e. from the academic model (selectively individualistic) to social democratic models, which are in part a consequence of liberalisation. However, as evident here and elsewhere, these models are not exclusively independent of each other. Noted elsewhere, it is quite unlikely that in a rapidly changing and increasingly global society, these educational purposes can be adopted to the exclusion of others. ${ }^{10}$ An emerging postmodern synthesis in which varieties of ideologies are united around the ideas of cosmopolitan theory has further been articulated ${ }^{11}$ In this paper, these ideologies serve as a basis to reflect on the structure and organisation of initial teacher education curricula in East Africa.

\section{A historical review of the development of formal higher education} in East Africa

The development of education in East Africa is indissolubly linked to missionary work, which started at the Kenyan coast as early as 1844 where the Church Missionary Society set up its first school. ${ }^{12}$ From then onwards, there was an influx of various missionary societies into the interior. The need for teachers and formalised teacher training arose immediately western education was established. Missionaries started teacher-training centres with the aim of having a critical mass of teachers who would foster the transformation of the socio-economic life of Africans by teaching them how to read and write, and practical skills. Underlying missionary education was the development of moral and character training, which paved way for British colonial interest and eventual administration of East Africa.

Through recommendations from a series of commissions during the colonial period e.g. the Phelps-Stokes Commission on education in East Africa (1924) and the British Government White Paper on Education in Tropical Africa (1925), a more formalised initial teacher education programme in higher education took shape. In 1925, Makerere College started administering a three-year in-service teacher-training programme for upper primary teachers. The College was later transformed into the sole inter-territorial higher education institution training secondary school teachers; and became the University College of East Africa in 1949 when it was affiliated to the University of London. This led to the establishment of a

${ }^{10}$ Judy Woon Ye Ho, Language and Education (2002).

${ }^{11}$ Chris Yates, UNESCO (2007), 3.

12 John C. Ssekamwa, History and Development of Education in Uganda (1997). 
Faculty of Education, which awarded postgraduate diplomas and teaching certificates. The Royal Technical College of Nairobi and the Dar es Salaam Technical College obtained similar status and relation with the University of London between 1958 and 1961. Although in 1962, Makerere introduced the Bachelor of Education degree course, which was felt would salvage teacher shortage in the region as independence was approaching, there seemed to be a more desperate need in Kenya for graduate teachers than Makerere alone could supply. As a result, a Department of Education was set up at Nairobi University College to provide undergraduate courses in Arts and Science with Education.

In a bid to respond to the needs of independent East Africa, affiliation to the University of London was dissolved in 1963. From 1964 onwards, Makerere University College, the University College of Nairobi and the University College of Dar es Salaam constituted the University of East Africa, with the mandate to examine and approve proposals for new faculties, departments, courses and subjects of study submitted to it by the constituent colleges. ${ }^{13}$ This move was among the precursors for cooperation, which culminated in the formation of the East African Community in 1967.

During the colonial period, the East African countries had a harmonised education system through established regional organisations and institutions. The East African National Examination Council ensured standardisation and quality assurance of education. ${ }^{14}$ Despite this joint effort, each independent state was desperately concerned with the need to train quality high-level manpower urgently needed for political and socio-economic development. Higher education was the viable solution to this problem. Dissatisfaction with the current training situation led to the dissolution of the University of East Africa in 1970. Each of the three university colleges became an independent national university of its respective republican government offering undergraduate and postgraduate courses leading to their own awards. However, in order to oversee and ensure systematic progress of the universities and further maintain academic cooperation among the universities, an Interim University Committee for East Africa was established..$^{15}$ With the collapse of the East African Community in 1977, further regional cooperation was discontinued, an indication that regional arrangements have not been successful in the past because political and other nationalistic considerations have reigned supreme over regionalism. It is

${ }_{13}$ John C. Ssekamwa, History and Development of Education in Uganda (1997).

${ }^{14}$ Inter-University Council for East Africa, "Regional higher education qualifications gaps versus the region's human resources needs" (June, 2014, 32, Unpublished).

${ }^{15}$ University of Dar es Salaam Prospectus (1990/91), 9. 
upon this background that the author seeks to review the structure and organisation of initial teacher education in the post- independent and contemporary East African universities.

\section{Findings from the review}

\section{Initial teacher education curricula and the ideologies embodied in the post-independent East universities}

Post-independent East Africa (mid-1960s to the mid-1980s) is characterised by expansion of initial teacher education programmes to meet teacher demand in secondary and post-secondary institutions. The University of East Africa (1963-1970) groomed two types of prospective teachers, namely holders of a non-graduate diploma and postgraduate diploma in education. The second lot had studied for a three-year degree in their respective academic disciplines followed by a one-year postgraduate diploma in education taught in the Faculty of Education. After 1965, the Faculty of Education (1952 and later School of Education, 1986), Makerere University College prepared teachers through two initial teacher education pathways, namely; the Bachelor of Education Degree (B.Ed.) and the Postgraduate Diploma in Education. Although the curriculum developed then was a little more adapted to the needs of East Africa than hitherto, ${ }^{16}$ Makerere's initial teacher education programme, which was modelled on the University of London model, was replicated in Kenyatta University College and at the University College of Dar es Salaam.

With the dissolution of the University of East Africa, the post-70s indicate further diversifications among universities offering initial teacher education. For instance, from 1983, in addition to preparing holders of the Postgraduate Diploma in Education, the concurrent Bachelor of Arts Degree with Education and Bachelor of Science Degree with Education programmes replaced the Bachelor of Education degree programme. Similarly, in 1989, the Faculty of Education at Dar es Salaam University offered a three and a half-year Bachelor of Arts with Education degree leading to a concurrent academic and professional certification. The half a year was dedicated to intensive practical work in schools. Despite political turmoil in Uganda, continuous strikes by university students in Kenya and the gradual adjustment to democratic governance in Tanzania, diversification of initial teacher education programmes in the then three public universities registered progressive increase in student enrolment.

\footnotetext{
${ }^{16}$ DIES $1113^{\text {rd }}$ Dialogue on Innovative Higher Education Strategies (2003), 19.
} 
However, Kenya's higher education is noted to have expanded faster than her counterparts due to her free enterprise economy and the unlimited expansion of secondary education..$^{17}$ In 1985 , the Kenyan government abandoned the then English 7-4-2-3 education system in East Africa i.e. seven years of primary education, four years of ordinary level education, two years of advanced level secondary education and three years of university education. Kenya adopted the 8-4-4 system of primary, secondary and higher education, respectively. Consequently, Kenyatta University started offering a fulltime four-year Bachelor of Education programme. This shift rendered Kenya's education system considerably different from that of Uganda and Tanzania, and has to date implications to the harmonisation of initial teacher education curricula within the East African Community.

Despite such divergences, the initial teacher education curricula in East African universities were quite similar. Ideologically, university role was redefined from elitism to social inclusiveness. It is noted that African political leaders and academicians wanted universities to apply "their energies directly to the practical solutions to social, economic, and political problems of their nations... actively participate in ideo-cultural regeneration, social transformation, economic modernisation ..."18

Therefore, there was demand to not only embrace modernisation, but also decolonise society and restore African identity. This was evident in the courses that were introduced in education faculties, e.g. African History, Oral and African Literature. Despite this shift, there was a blend of 'ivory tower mentality', utilitarianism and social re-constructionist ideologies, which was intended for academic advancement and national development. University knowledge then ceased to be knowledge for its own sake, but knowledge with an application purpose. Demand for manpower led to a qualitative and quantitative expansion of university education, in terms of programmes offered and student enrolment. An upward trend in the number of graduates justified the existence of universities. ${ }^{19}$

Following the Makerere University model, each education faculty had on average five departments teaching methods courses, adult education, history and philosophy of education, curriculum studies, economics of education and administration, educational technology, psychology and sociology. ${ }^{20}$ Consequently, this led to duplication rather than specialisation of courses,

${ }_{17}$ Sorobea N. Bongoko, A history of modern education in Kenya (1895-1991), (1992), 143.

18 Sorobea N. Bongoko, A history of modern education in Kenya (1895-1991), 146.

19 Sorobea N. Bongoko, A history of modern education in Kenya (1895-1991), 143.

${ }^{20}$ ESAURP - Eastern and South African Universities Research Program, University capacity in Eastern and Southern African Countries (1987). 
and rendered inter-territorial exchange of students and staff of no consequence. Another structural similarity was inter-faculty involvement in the preparation of prospective teachers. Those who enrolled for a three-year degree course were taught from two faculties, i.e. the faculty of education and either, the Faculty of Arts, Social Sciences or Sciences. In the former, prospective teachers undertook professional studies and subject methods courses, while in the latter they had detailed scientific exposure in their respective teaching subjects. For sound academic and professional grounding, all subjects offered were essential. In the fourth term of their second and third year university studies, prospective teachers undertook school practice in secondary schools for a specified number of weeks; quite often determined by resources. Following the classical humanism ideology, academic exposure during training was intended to equip prospective teachers with relevant theories and attitudes as basic prerequisites for practical training.

The Bachelor of Education, the Bachelor of Arts and Bachelor of Science with a concurrent Diploma in Education programmes were hoped to instil professionalism among the prospective teachers. However, teacher preparation from a variety of departments and faculties compromised the holistic professional growth of prospective teacher. Lecturers from the other faculties did not have a teaching qualification, making it difficult for them to organise and teach content relevant in teacher preparation. Similarly, in these and earlier structural arrangements, teacher educators had no practical experience at the lower levels of education such as secondary schools ${ }^{21}$. Nonetheless, even where several disciplines were merged under one department within the Faculty of Education itself, the boundary between them was maintained. ${ }^{22}$ Such a curriculum is termed as a 'collection code' where disciplines are made up of a discrete study of segregated elements. ${ }^{23}$ Characteristic of such a curriculum is that the teacher educator has clear control over the selection, pacing and organisation of knowledge, which Bernstein refers to as framing. When the framing is strong, the teacher controls the knowledge transmitted, and when weak, students control the content. In the case of the two initial teacher education programmes, framing was strong, which encouraged the use of teacher-centred pedagogy. By 1987 Makerere University had the most unfavourable teacher-student ratios

${ }^{21}$ Yoweri K. Bamanyaki, "Teacher education programmes and teacher effectiveness in Uganda” (Unpublished M.Ed. Dissertation, Makerere University, Kampala, 1979).

${ }^{22}$ Bonny Busingye, "Teacher education in the School of Education at Makerere University" (Unpublished M.Ed. Dissertation, University of Manchester, 1989).

${ }^{23}$ Basil Bernstein (1971) cited in Initial teacher training and the role of the school by John V. Furlong, Paul H. Hirst, Keith Pocklington and Johnstone S. Miles (1988):123-124. 
among the universities in the region, i.e. a ratio of $1: 60$ compared to $1: 16$, the average ratio in the region; ${ }^{24}$ a further justification for a strong curriculum framing. Such ratio provided the basis for a teacher-centred pedagogy, which had strong reference to the then pedagogical ideology pervading university teaching.

The three-year Bachelor of Arts and Bachelor of Science with a concurrent Diploma in Education programme was further criticised for overloading prospective teachers, since these studied for two qualifications i.e. a degree and diploma in education. Consequently, the graduates used their degree qualifications to acquire jobs elsewhere, ${ }^{25}$ a move that did not salvage lack of qualified teachers for secondary and post-secondary institutions. Following the misallocation and under-utilisation of those trained, a concurrent Bachelor of Arts and Bachelor of Science with Education degree course was introduced at Makerere University in 1982. This programme has withstood the test of time despite criticism that it is overstretched in content and organisation. On the other hand, Kenya and Tanzania have continued with the Bachelor of Education degree programme, although Tanzania also runs the Bachelor of Arts and Bachelor of Science with Education degree programme at the same time. The Bachelor of Education equally continued to be offered at Makerere University to students following the distance education mode, as well as by Kyambogo University.

Based on the above review, there seemed to be dissatisfaction with the post-independent initial teacher education system in East Africa. The education system was generally described as:

.... a foreign thing wrenched from a European environment and erected in a society to which it is not related. The programmes it offers are bookish and are geared to preparing pupils for higher education which still remains the prize goal of a small number of pupils. ${ }^{26}$

Characteristic of bookish education is student exposure to an array of summative examinations, which further stifles initiative and innovation in learning. Such a system discourages the preparation of students for life in society, but promotes search for white-collar jobs in urban centres after graduation. Due to the selective nature of the summative examinations, such a system cannot fulfil the 'greatest happiness for the greatest number'

${ }^{24}$ ESAURP - Eastern \& South African Universities Research Program, University capacity in Eastern and Southern African Countries.

25 Bonny Busingye, "Teacher education in the School of Education at Makerere University” (Unpublished M.Ed. Dissertation, University of Manchester, 1989).

${ }^{26}$ Samuel Lugumba \& John C. Ssekamwa, A History of Education in East Africa (19001973) (1973). 
advocated by utilitarianism. Higher education in general and initial teacher education in particular continued to be exclusively fashioned for a small minority group; mainly sons and daughters of kings, chiefs and affluent Africans serving in colonial and post-independent governments. According to a report from University of Dar es Salaam, post-independent [higher] education had an 'ivory tower' mentality because it was hardly accessible by ordinary people and hardly obliged to reach out to the rest of the community in relation to the mundane matters of everyday life. The report adds:

Under this guise, institutions of higher learning - not least universities particularly of the first generation in their own country of location - were feared, yet revered for their isolationist stance from public life: perceived as "sacrosanct" for the "exclusive knowledge" they produced; untouchable and unquestionable even in the face of some obvious criticism that could possibly be raised against them. ${ }^{27}$

Despite effort to Africanise education, the above image reflected an education not only elitist, but also repulsive. Indeed, in the process of nation building, African universities were expected to develop and modernise their countries along western lines. ${ }^{28}$ Coupled with the above were nationalistic ideologies in which the desire to produce adequate quality labour was urgent and sentiments to indigenise education were strong. Such an education system can be described as a hybrid of cultural ideologies, which reflected and were in turn reflected in the socio-economic and political spaces in which these universities were located. Therefore, post-independent East African initial teacher education curricula blended neo-colonialism, indigenisation and a dose of globalisation. This historical setting played a significant role in shaping the character of contemporary initial teacher education curricula in East African universities, to which the author now turns.

\section{The structure and organisation of initial teacher education} in the contemporary East African Universities

The contemporary period started in the mid-1980s to date, a period within which various policy reforms in East Africa targeted initial teacher in education and quality. Indeed, in the words of the Uganda Government

${ }^{27}$ University of Dar es Salaam, "Undergraduate programs and administration procedure" (Office of the Deputy Vice Chancellor for Academic, Research and Consultancy, 2007).

${ }^{28}$ Daniel W. Nabudere, Southern African Review of Education, A Journal of Comparative Education and History of Education (2007), 126. 
White Paper on Education, it is the quality of teachers, which ultimately determines the lot of the nation. ${ }^{29}$ Similar arguments regarding teachers being at the epicentre in the realisation of a quality education process are echoed elsewhere. ${ }^{30}$ Although East African governments acknowledged the importance of teacher quality, they could not single-handedly meet their respective country's educational demands. The decline in state funding and the formulation of market-friendly reforms initiated under the World Bank Structural Adjustment Programmes created an encouraging environment for the emergency of the private higher education sector in Africa, ${ }^{31}$ which is todate fast growing.

Through the Kamunge Report (1988) that recommended cost sharing in education and the establishment of private and Harambee institutions, and with support of World Bank policies, Kenya became one of the first African countries where public and private universities peacefully coexisted. ${ }^{32}$ In the mid-1990s, the private sector establishment in Uganda and Tanzania followed suit. To date, there is registered expansion of private programmes at public universities and private higher education institutions; and progressive increase in the gross enrolment ratios from for instance below 1,0 in 1980 to 3,0 in 2000 in Kenya and Uganda. ${ }^{33}$ Citing Uganda, Liang ${ }^{34}$ posits that "...the demand for tertiary education will continue to grow as the success of the UPE [Universal Primary Education] campaign works its way through the education system and as the target tertiary age expands."

On a similar note, in the State of Higher Education Report, ${ }^{35}$ the private sector owned $73 \%$ of the 187 higher education institutions in Uganda by 2011 , representing a $4 \%$ growth in private ownership of higher education institutions and no absolute growth in government ownership of institutions. Elsewhere, private higher education has been noted to be one of the most

29 Uganda Government, White Paper on Education (1992), 152.

${ }^{30}$ Chris Yates, "Teacher education policy: International development discourse and the development of teacher education," 3; Martin Carnoy, "Lessons from the past two decades: investment choices for education and growth"; John Schwille and Martial Dembélé, "Global perspectives on teacher learning: Improving policy and practice," 5-26.

${ }^{31}$ Varghese N. V., Private Higher Education in Africa, 4; Festus Kaberia, Joyce M. Mutinda, and Margaret K. Kobia, "Regulation and quality assurance mechanisms for transnational (Commercial) providers of higher education in Kenya".

${ }^{32}$ Varghese N.V., Private Higher Education in Africa.

${ }^{33}$ UIS - UNESCO Institute of Statistics, "Database Website", 2003.

${ }^{34}$ Xiaoyan Liang, Uganda Tertiary Education Sector, Africa Region Human Resource Development (World Bank, Africa Region, 2004, 15).

${ }^{35}$ National Council for Higher Education, "The State of Higher Education Report" (2012). 
dynamic and fastest growing segments of post-secondary education at the turn of the $21^{\text {st }}$ century. ${ }^{36}$

From one university in 1970, Kenya now boasts of 39, Uganda has 34 while Tanzania has $52 .{ }^{37}$ Majority of the universities within the region are private, and majority have faculties of education. However, there is a misconception that education faculties need limited investment in infrastructure and equipment, and are therefore cheap to set up and manage. Nonetheless, this is an indicator of a fast growing higher education sector within the region. In Uganda, the Makerere University Private Entry Scheme is referred to as the 'quiet revolution' ${ }^{38}$ because of its profound effects on the management of universities. ${ }^{39}$

Demand and privatisation of East Africa's higher education sector has gradually diminished the ivory tower mentality inherent during the colonial and post-independent periods. Focus is shifting from a select and exclusive population and its pursuit for abstract ideas to universalisation. Strong links between society and university are becoming more evident, extending, diversifying and making universities socially inclusive. A vivid example is the establishment of Public-Private-Partnerships (PPPs). Consequently, initial teacher education aims have shifted from only targeting the local to embracing a regional and global market. ${ }^{40}$ According to Goodwin, globalisation "introduces new factors that demand consideration in any discussion about quality teachers, and promises to change fundamentally the very nature of teacher preparation." ${ }^{41}$ Reviewing various education faculty vision and mission statements, universities aim at becoming leading centres of excellence in scholarly and professional fields; world-class universities responsive to national, regional and global development agendas, and bringing about equitable and sustainable socioeconomic development within and beyond their respective countries. For

${ }^{36}$ Philip G. Altbach, "Comparative Perspectives on Private higher education," in Private Prometheus: Private Higher Education and Development in the $21^{\text {st }}$ Century, ed. Phillip G. Altbach (West Port, Greenword Press, 1999).

${ }^{37}$ Inter-University Council for East Africa, "Regional higher education qualifications gaps versus the region's human resources needs," 46.

38 "Report of the Visitation Committee to Public Universities" (Unpublished, 2007).

39 Bidemi Carrol, "Harnessing private monies to fuel university growth," Southern African Review of Education, A Journal of Comparative Education and History of Education 13, no. 2 (2007): 77-92.

${ }^{40}$ Also refer to NCHE - National Council for Higher Education, Quality Assurance Framework for Universities and the Licensing Procedure for Higher Education Institutions, Kampala: NCHE, 2008).

${ }^{41}$ Lin A. Goodwin, Teaching Education (2010), 20. 
instance, the mission of the College of Education and External Studies (CEES), Makerere University is:

To excel in the preparation of teachers, other education practitioners, adult education providers, community workers and providers of open, distance and e learning; to excel in research and in knowledge transfer and partnership relevant to CEES and responsive to national and global needs. ${ }^{42}$

Further, common in institutional objectives is accomplishing and applying research, bridging theory and practice, lifelong-learning and sustainable individual and societal development. Society is expected to receive teachers, lecturers, education managers and administrators competent to adapt to present and emerging demand for skills, knowledge and practices relevant to educational research and services, to support national, regional, and international development. ${ }^{43}$

From the foregone review, two forces have simultaneously influenced the current structure and organisation of higher education in general. As Varghese ${ }^{44}$ notes, the birth of a market ideology has provided a smooth transition of the economy to a process of globalisation, with a knowledge economy, which depends on information technology as one of the most sought-after sector in this process. Since national competitiveness in the knowledge economy depends on the availability of highly educated persons, university education has become a centre of focus. The second force that has increased demand and access to higher education at domestic level is the desire for social upward mobility and the equating of higher education with better jobs and social status ${ }^{45}$. From the utilitarian and social re-constructionist outlooks, higher education is directly linked to the development of individuals and society as it supplies the labour market with the needed skilled manpower, contributes to poverty alleviation, and empowers society with skills to produce goods and services needed for better living. Therefore, initial teacher education curricula from both public and private universities play a complementary role in meeting academic and market demands, an example of a mixture of public and private ideologies, which were rare prior to the mid-1980s.

Evident in institutional literature on initial teacher education is the emergency of new market-oriented vocabulary such as 'clientele', 'client-

${ }^{42}$ Makerere University College of Education and External Studies Strategic Plan $(2011 / 12-2018 / 19)(2011,4)$.

${ }^{43}$ Makerere University College of Education and External Studies Strategic Plan (2011/12-2018/19) $(2011,1)$.

${ }_{44}$ Varghese N.V., Private Higher Education in Africa.

${ }^{45}$ NCHE - National Council for Higher Education, "Strategic Plan" (2007), 1. 
driven curriculum,' 'customer satisfaction,' 'customer care', and the 'customer is king.' Stated differently, Brennan ${ }^{46}$ describes higher education as reflecting:

...contemporary management theory as developed in manufacturing and service industries. It is a language which can turn students into customers, academic staff into producers/providers, universities into businesses and their departments into profit centres.

Brennan's description shows the extent to which market ideology and terminology has permeated higher education in general. Moving from being a public service, education has become a commodity sold and bought on the open market. According to the National Council for Higher Education, ${ }^{47}$ education has ceased to be the privilege of the elite and become a product where education institutions are the merchants with products to sell and students the customers ready to buy these products. ${ }^{48}$ However, beneath such vocabulary, are undertones of educational inequality and de-professionalisation in the face of a competitive environment. For example, private initial teacher education curricula targets prospective teachers who can pay tuition and other university levies. Since these students are from middle and highincome backgrounds, higher education, and consequently, the employment market either maintains or improves their social status, which according to Varghese ${ }^{49}$ widens the intergenerational inequalities. This brings to question the role of the private sector in reconstructing society.

Market-friendly vocabulary is influenced and in turn influences universities to internationalise initial teacher education curricula to meet the needs of student, staff and programme mobility. For instance, in Uganda, the number of international students increased by $7 \%(7,735)$ in 2005 to $9.4 \%$ $(12,930)$ in 2006 to 16,244 in 2010 and to 17,156 in 2011, making education the fourth highest external earner. ${ }^{50}$ Such transnational or borderless tertiary education is a response to globalisation, which requires universities to align their courses to international standards. Consequently, current effort within the East African Community (EAC) is to:

46 Timothy Brennan (1997, cited in DIES $111-3^{\text {rd }}$ Dialogue on Innovative Higher Education Strategies, 2003, 36).

${ }^{47}$ NCHE - National Council for Higher Education, "The State of Higher Education" (2012), 2 .

${ }^{48}$ See also Ronald G. Sultana, Studying Teacher Education (2005), 226.

49 Varghese N.V., Private Higher Education in Africa, 24.

${ }^{50} \mathrm{NCHE}$ - National Council for Higher Education, Quality Assurance Framework for Uganda Universities, (NCHE: Kampala, 6, 2006); NCHE - National Council for Higher Education, The State of Higher Education $(2012,2)$. 
...introduce a Regional Higher Education Qualifications Framework (RHEQF), as part of a strategy to achieve region-wide skills development and employment goals, and as a measure of comparability, internationalization of qualifications, and fulfillment of the tenets of the Treaty Establishing the East African Community. ${ }^{51}$

As a major education reform instrument, the qualifications framework if well conceptualised and implemented by partner states will strengthen the relevance and flexibility of education and training programmes, ease recognition of prior learning, enhance lifelong learning, improve the transparency of qualification systems, create possibilities for credit accumulation and transfer, and support the development of quality assurance systems. ${ }^{52}$

Another example is the approval and certification of education institutions and programmes by the Kenya Bureau of Standards on behalf of the International Organisation for Standardisation (ISO). The aim is to internationalise and avoid duplication of programmes. In this case, we refer to ISO Certified graduate teachers 'Made in Kenya', who with this trademark can teach anywhere in the world. Such moves further strengthen the argument of a paradigm shift of initial teacher education curricula from a professional to a market-driven sub sector, where competences and value for money are major foci.

Internationalisation of initial teacher education has encouraged education faculties to diversify their curricula in order to attract a variety of students. Apart from the direct entry scheme for high school students, universities have devised entry schemes for mature age entrants, for holders of relevant diplomas, postgraduate degree, and other professional qualifications. Further, in addition to conventional initial teacher education degree programmes, universities have introduced Open Distance and eLearning programmes with a bid to surmount geographical barriers to access to education and training. A further contemporary development is the establishment of outreach centres or university branches in the communities under the slogan 'bringing services closer to the communities.' Through these flexi-programmes, more students can study anywhere in the evenings, weekends, or during holidays. The internationalisation and diversification of initial teacher education sustains the social re-constructionist values of equity, tolerance and

${ }^{51}$ Inter-University Council for East Africa, Jumuiya ya Afrika Mashariki, East African Business Council, Regional higher education qualifications gaps versus the region's human resources needs (2014).

${ }^{52}$ Inter-University Council for East Africa, Jumuiya ya Afrika Mashariki, East African Business Council (2014). 
democracy. However, students who are admitted to train as teachers are not top-achievers at high school compared to their counterparts admitted for engineering law and medicine. ${ }^{53}$ In the Kenyan Ministry of Education, Science \& Technology Report ${ }^{54}$ the following observation was made: 'the quality of the teaching force is also affected by the fact that many teachers take their teaching career as a last and only available option.' Similar trend is noted in some Latin American universities where teaching is considered second choice..$^{55}$ This jeopardises the quality of teaching and learning both during and long after graduation.

The integration of thematic areas such as ICT, HIV/AIDS, entrepreneurship, environmental protection, gender and education, human rights, peace and ethics, food and nutrition, and local/international languages in current initial teacher education curricula is a further pointer to content diversification. For instance, Moi University runs a university-wide course in Human Resource Development aimed at empowering prospective teachers to find employment beyond the teaching profession within and outside Kenya ${ }^{56}$ Similarly, Mbarara University of Science and Technology in Uganda designed a course in Development Studies for all science students, and Makerere University introduced a Computer Applications Skills course for all undergraduate programmes. ${ }^{57}$ These career-field oriented courses add value to academic programmes by providing students with a broad-based contemporary outlook to the world of work after graduation.

Unfortunately, fast changes in the knowledge economy have not been matched with appropriate changes in initial teacher education curricula, which can be described as slow and in some cases barely discernible. The structure and organisation of initial teacher education is still predominantly the same as the one in the post-independent period. Universities in East Africa generally follow a two-phased model, where theoretical training is first accomplished at university followed by practicum in schools. Amid concerns of curriculum overload, theoretical studies take the greater portion of formal initial teacher preparation i.e. over three-quarters. Although the schools and faculties of education oversee both training phases, the practicum

${ }^{53}$ Also refer to Abel G. M. Ishumi, Africa Education Review $(2013,98)$.

${ }^{54}$ Republic of Kenya, Development of Education in Kenya, (Ministry of Education, Science \& Technology, Nairobi, Kenya, 2004, 20).

55 Beatrice Avalos, Teacher education in the Latin American region: an unfinished business, Southern African Review of Education, A Journal of Comparative Education and History of Education, Vol. 14, Nos. 1-2; 9-27, (2008).

${ }^{56}$ Ruth N. Otunga, "A comparative study of Makerere University and Moi University Schools of Education (An unpublished study, 2005).

${ }^{57}$ Makerere University, College of Education and External Studies Strategic Plan (2011). 
is given less time, and the theory-practice dichotomy has not been given adequate attention..$^{58}$

During university preparation, subject matter content is taught separately from pedagogical and professional studies. The faculties of Social Sciences/ Social Cultural and Development Studies, Arts and Science have since the introduction of university initial teacher education been mandated to teach subject matter content while the education faculties teach the professional and pedagogical aspects. In such arrangement, teacher educators are likely to have limited authority regarding subject matter content and its delivery. Subject matter content specialists in the other faculties are in the least concerned about the professional and pedagogical values informing those disciplines in light of teacher preparation. The subjects specialists will teach the way they were taught unless there are formal interventions to support them achieve the goal of teacher preparation. Elsewhere, lack of teacher educators trained in teaching methodologies, cooperation and learning appropriate for adult learners has been cited as one of the most challenging tasks facing educators today. ${ }^{59}$

In some universities, the question of ownership of students has led to near conflict between faculties. Consequently, graduate teachers have to integrate what the university has failed to integrate. In cases where education faculties have attempted to 'domesticate' the initial teacher education programme tailored to the needs of school curricula, faculty mandates and other clandestine motives have blocked such move. This is especially so in public universities such as Makerere University offering parallel private initial teacher education programmes. A future threat is the transformation of education faculties into servicing units in universities. ${ }^{60}$ This form of institutionalised separation is common in the concurrent initial teacher education model still predominant in the preparation of secondary school teachers in East Africa. However, similar separation has been noted in consecutive models, for instance in Germany where teacher training is described as lacking in coordination between the two phases, and among the university departments responsible for teacher training leading to a separation between academic and professional subjects. ${ }^{61}$ Such arrangement that

58 Proscovia Namubiru Ssentamu, Bayreuth African Studies (2006).

59 OECD International Seminar on Teacher Education Diversity, (2010); Friedrich Buchberger, Bártolo P. Campos, Daniel Kallos, and John Stenvenson, Eds., "Thematic Network for Teacher Education in Europe (TNTEE)" (Umea University, Sweden, 2000), 56.

${ }^{60}$ Bidemi Carrol, "Harnessing private monies to fuel university growth," Southern African Review of Education, A Journal of Comparative Education and History of Education 13, no. 2 (2007): 86.

${ }^{61}$ Proscovia Namubiru Ssentamu, Bayreuth African Studies (2006); Ulrich Herrmann, Pädagogische Rundschau Heft (2001). 
separates university studies from school-based training and detaches faculties and departments responsible for initial teacher education from each other makes holistic teacher development reforms difficult to design, implement and evaluate.

Unlike in East Africa, in the US and in England, universities through both government and institutional initiatives are much more vigilantly involved in school. According to Schwille \& Dembélé, ${ }^{62}$ this close link is through consultancies and participation in various aspects of initial teacher education and school life in areas such as needs assessment, advisory panels, and collaborative projects. Although such collaborative opportunities may be present between initial teacher education institutions and schools in some universities in East Africa, not much is documented in this area, an indicator that much of what happens is still informal and on small scale. However, one danger of such casualness is that universities become unaware of the opportunities and challenges pertaining to schools and their effect on initial teacher education curricula, leading to a weakening of subject content matter, pedagogical content and school reality.

Related to the above structure is the differentiation of initial teacher education degree programmes. While for instance Moi University (Kenya) and University of Dar es Salaam (Tanzania) award six various B.Ed. degree programmes, ${ }^{63}$ Makerere's College of Education and External Studies still conforms to the post-independent Bachelor of Education, Bachelor of Arts with Education and Bachelor of Science with Education Degree programmes, which are rigid in structure. Yet, Makerere University still provides the benchmark for other public and private universities offering initial teacher education, especially in Uganda.

The number of departments within the education faculty nomenclature was yet another structural legacy passed on during the post-independent period. To date, there are six distinct departments in the faculties of education offering initial teacher education at Makerere University and seven in the University of Dar es Salaam and at Kenyatta University. The time-honoured departments common in these universities are the professional departments, i.e. the Department of Educational Foundations and Management, Department of Curriculum, Teaching and Media, and Department of Educational Psychology, and the School/Teaching Practice Unit. These resonate with the key quality indicators in a typical initial teacher education programme,

62 John Schwille and Martial Dembélé, "Global perspectives on teacher learning: Improving policy and practice."

${ }^{63}$ Ruth N. Otunga, "A comparative study of Makerere University and Moi University Schools of Education"; UDSM, "Undergraduate programs and administration procedure." 
which are content knowledge, foundation courses, pedagogical courses and teaching practice. ${ }^{64}$

However, in England and Wales, professional studies are highly contestable as they are claimed to promote intellectualism, thereby calling for a movement 'back to the schools. ${ }^{65}$ In the East African education faculties, foundational disciplines, i.e. educational psychology, foundations of education and curriculum studies were and still are a rich source of classical humanism and essentialism in which tradition is established and beliefs and practices are endorsed as basic requirement for prospective teachers. According to $\mathrm{Ho}^{66}$ a distinctive aim of this tradition is to maintain the cohesiveness and orderly development of institutions and of the myths and rituals engendered by these institutions. Therefore, induction into institutions means acceptance of defined values and standards and articulated modes of thought and action. ${ }^{67}$ Another reason for the gradual transformation in course content is that the departmental structures are still rigid restraining the promotion of multi-disciplinary and contemporary studies and research. Departments have consequently provided good breeding ground for duplication of course content even within the same teacher education faculties.

Initial teacher education curricula is hitherto defined as subject- and teacher-centered, and heavily reliant on examinations. Elsewhere, the following was noted: "In British tradition, assessment of undergraduate work has tended to place a heavy emphasis on a formal and comprehensive final examination, whereas the North American approach tends to stress continuous assessment." ${ }^{68}$

Although the survey adds that many third world universities after following one of these forms of assessment, found neither system perfect on its own, and have therefore tended to adopt features from both systems; there is still heavy emphasis on written summative examinations targeting the recognition of competencies based on formal education rather than competencies required for the workplace and for life-long learning. ${ }^{69} \mathrm{In}$

${ }^{64}$ Friedrich Buchberger, Bártolo P. Campos, Daniel Kallos, and John Stenvenson, eds., "Thematic Network for Teacher Education in Europe (TNTEE)."

${ }^{65}$ Michael Eraut (1994), cited in Moira Hulme and Ian Mentor, "Learning to teach in post-devolution UK: A technical or an ethical process."

66 Judy Woon Ye Ho, Language and Education, 287.

${ }^{67}$ Malcolm Skilbeck (1982 cited in Judy Woon Ye Ho, Language and Education).

${ }^{68}$ ESAURP - Eastern and South African Universities Research Program, "University capacity in Eastern and Southern African Countries," 93.

${ }^{69}$ Inter-University Council for East Africa, "Regional higher education qualifications gaps versus the region's human resources needs". 
addition, school practice is generally undertaken at the end of year two and year three for less than two months, rather than having it running concurrently during university education. This situation is further exacerbated by constraints on the resources of education providers, poor resource prioritisation, ${ }^{70}$ the hesitancy of employers to invest in training, ${ }^{71}$ and political interference as has been cited in Tanzania and Uganda. ${ }^{72}$

There is a proposal for a regionally-based assessment reform to introduce the credit accumulation and transfer (CAT) system, which is aimed to permit student mobility from one institution or programme to another, thereby removing related barriers. Although the CAT system has not yet materialised, with the move towards a regional qualifications framework, the development of the CAT system is likely to lead to an over-concentration by students on grades in a bid to join better regional universities. Although such move responds to the utilitarian purpose of education, it defeats the social reconstructionist purposes since it promotes competition and exclusion. Further, majority of East African universities are implementing assessments based on competences or learning outcomes, an imposition on teacher educators by the business community, the respective higher education councils or commissions, and the national governments. Because teacher education institutions ought to be performance-based, competences facilitate quality control procedures. By the end of an initial teacher education programme, prospective teachers should have acquired a number of centrallydefined competences corresponding to sets of knowledge, skills and attitudes. Related observations are made regarding initial teacher education in England and Wales. ${ }^{73}$ However, the competence-based model has been criticised for fostering apprenticeship approaches in initial teacher education to the detriment of professionalism, and critical and reflective thinking skills. ${ }^{74}$

Despite the many reforms taking place in East African education faculties and schools, there has not been adequate emphasis on the quality of teaching. Most of the teacher educators are former students in their respective initial teacher education institutions, with only a few having experience teaching at tertiary, secondary and primary school levels. The minimum

${ }^{70}$ Damtew Teferra and Philip, G. Altbach, Higher Education, 26.

${ }^{71}$ Inter-University Council for East Africa, Jumuiya ya Afrika Mashariki, East African Business Council $(2014,106)$.

72 Abel G. M. Ishumi, Africa Education Review, 98.

${ }^{73}$ Moira Hulme and Ian Mentor, "Learning to teach in post-devolution UK: A technical or an ethical process".

${ }^{74}$ Proscovia Namubiru Ssentamu, Bayreuth African Studies (2006); Friedrich Buchberger, Bártolo P. Campos, Daniel Kallos, \& John Stenvenson, eds., "Thematic Network for Teacher Education in Europe (TNTEE)," Umea University, Sweden, 2000. 
qualification for university teachers is a first class or upper second-class honours degree. This Bachelor's teacher-training-a-Bachelor's student scenario leads to recycling of content, pedagogies and assessment procedures in initial teacher education, which eventually has a trickle-down effect on the other levels of education. As cited in a report from the Republic of Kenya, 'teacher trainers at the university are not professional teachers and yet they are charged with the responsibility of preparing teachers to be professionals"75. Similar examples are cited in Uganda and Tanzania where fresh graduates from faculties of education immediately take up teaching posts in the faculty with no teaching experience. Apart from their teaching responsibilities, these beginning teachers-cum-teacher educators supervise student teachers during school practice. In essence, they learn on the job as they role model their professors. Elsewhere, the pedagogy of the pre-service programme in the United States mirrors the pedagogy of higher education where lectures, discussions, and seat-based learning are coins of the realm ${ }^{76}$. In England and Wales, $50 \%$ of the Post-Graduate Certificate of Education programme is school-based. ${ }^{77}$

Further, teacher educators do not practice what they preach, i.e. "do what I say, but not what I do," making classes either too abstract to challenge deeply held beliefs or too superficial to foster deep understanding. Such inconsistency between what is taught and how it is taught is added confirmation of the lack of professional training of teacher educators within the East African Universities.

\section{Conclusion}

There are consistent findings from the current study regarding the development of initial teacher education in East African universities. This consistency is explained by propinquity and similarity in colonial history and culture these countries share. Colonial roots continue to shape the future of initial teacher education within the region. The author acknowledges changes such as the shift from term to semester system, and diversification in the Bachelor of Education programmes in education faculties in Kenya and Tanzania. However, due to lack of national initial teacher education frameworks

${ }^{75}$ Republic of Kenya (2004), 20.

${ }^{76}$ Sharon Feiman-Nemser, Teachers' College Records, 1020.

77 Janet S. Stuart and Maria Teresa Tatto, "Designs for initial teacher preparation programs: An international review," 493; Proscovia Namubiru Ssentamu, Bayreuth African Studies (2006). 
to guide curricula in the individual states, much is still the same in terms of structure and organisation. It is hoped that the situation will change with the rejuvenation of the East African Community and the continued role of the InterUniversity Council for East Africa in the harmonisation of curricula, examination, certification and accreditation of education and training institutions in the partner states through regional qualifications framework and the joint action of the respective national councils and commissions of higher education.

Similar patterns of convergence and divergence are cited in the Green Paper on Teacher Education in Europe. ${ }^{78}$ The paper stresses the unique combination of distinctiveness and commonality between the systems of initial teacher education which exist in Europe, with variations at cross-border, national and institutional levels, and with several initial teacher education models cohabiting within a single member state. ${ }^{79}$ However, it is further argued that these differences are mainly structural ones, but that the principles and curricula of initial teacher education in the various member states do not necessarily differ very much given that most institutions across Europe are 'influenced by similar traditions and hidden curricula. ${ }^{80}$ Further, similar to the European Higher Education area, the East African national councils or commissions for Higher Education in collaboration with the Inter-University Council for East Africa are mandated to advance and secure student mobility, promote regional quality standards, and competitiveness in the labour market.

Alongside the colonial legacy are market ideologies, which play an upper hand in the struggle of education faculties to survive in a globally competitive market. However, due to high student gross enrolment rates and lack of a strong resource base, quality has taken a secondary seat. This has also affected equity in higher education in that students from poor socialeconomic backgrounds have not been able to access higher education, even when they qualify. From an institutional perspective, equity also addresses itself to teacher educator quality, assessment and testing procedures, instructional materials, equipment, and infrastructure among others, which are disproportionate to the gross enrolment rates. Closely following this observation, although there is a definite shift from the behaviourist to constructivist and social constructivist ideologies of initial teacher education curricula in several East African universities using learning outcomes and

${ }^{78}$ Friedrich Buchberger, Bártolo P. Campos, Daniel Kallos, and John Stenvenson, eds., "Thematic Network for Teacher Education in Europe (TNTEE)."

${ }^{79}$ Friedrich Buchberger et al, "Thematic Network for Teacher Education in Europe (TNTEE)."

${ }^{80}$ Friedrich Buchberger et al, "Thematic Network for Teacher Education in Europe (TNTEE)." 
competences, the delivery and assessment strategies are still behaviourist in nature. This is due to among others lack of capacity of teaching staff to use competence-based approaches, teaching of course units or subjects independent of each other, infrastructure unmatched with student enrolment, and the generally examination-oriented culture. According to Goodwin, teacher education continues to operate according to the 'banking approach' to knowledge, operating an undifferentiated curriculum with discreet subjects ${ }^{81}$ Consequently, a well-designed and accredited competence-based programme remains on paper. This scenario relates well with that presented by Stuart and Tatto depicting cases in Mexico and South Africa where the roles expected of the trained teachers are inconsistent with the epistemological assumptions. More specifically, although the initial teacher education curriculum in these countries is transformative, the means available to deliver it are strongly influenced by a culture of transmission. ${ }^{82}$

As argued elsewhere, although initial teacher education in England and Wales has undergone massive changes over time and been replaced by models of modern competences ${ }^{83}$ the East African initial teacher education area still has strong traces of the old English model five decades after independence.$^{84}$ Among such changes in initial teacher education is the move to either abolish or minimise the role of pre-service initial teacher education institutions, in England and in the US ${ }^{85}$ Among the reasons advanced for such move is that pre-service teacher education programmes cannot develop capabilities needed for teaching to people who lack the necessary prerequisite strengths and general education and intellectual ability. ${ }^{86}$ It is also argued that pre-service teacher education programmes are not a cost-effective investment and therefore one could opt for very short pre-service programmes ${ }^{87}$ It is no surprise that the Postgraduate Certificate in Education in England and Wales is more popular than the undergraduate initial teacher education degree

${ }^{81}$ Lin A. Goodwin, Teaching Education, 28.

82 Janet S. Stuart and Maria Teresa Tatto, Designs for initial teacher preparation programs: An international review," 33 (2000): 500.

${ }_{83}$ Roy Gardner (1995).

${ }^{84}$ Damtew Teferra and Philip, G. Altbach, Higher Education, 24; Proscovia Namubiru Ssentamu, "A comparison of Ugandan, English and German teacher education models."

${ }^{85}$ Moira Hulme and Ian Mentor, "Learning to teach in post-devolution UK: A technical or an ethical process"; Derek Sankey, "The problematic of pre-service teacher education and its possible resolution at Hong-Kong Institute of Education".

${ }^{86}$ John Schwille and Martial Dembélé, "Global perspectives on teacher learning: Improving policy and practice".

87 John Schwille and Martial Dembélé, "Global perspectives on teacher learning: Improving policy and practice". 
programme. On the contrary, the role of schools and faculties of education in the provision of initial teacher education degree programmes is growing faster and stronger within the East African universities.

\section{Implications}

As education faculties in East African universities attempt to advance societal transformation, they should continually reflect on and address the values of access, equity and quality initial teacher education. The tension between quality and quantity indicates a tension between utilitarian and reconstructionist ideologies on the one hand, and market and global ideologies on the other. The practical question then is how education faculties can address both the public and private good functions of education, without the private good function of education superimposing itself over and above the public good. The education faculties could address themselves to the question posed by advocates of utilitarianism, i.e. "what is the role of educational institutions in preparing students for future employment and satisfying societal needs?" The faculties could also consider addressing the question social reconstructionists pose, i.e. "do educational institutions develop students' ability to improve and change society?" These two ideologies perceive learning as construction, which involves not only making meaning out of knowledge and experience, but, being able to negotiate meaning as opposed to transmitting and appropriating information to be recalled and applied in examinations. ${ }^{88}$

The current review has demonstrated the existence of a hybridism in ideology in East African education faculties in which the post-colonial and the contemporary, the public and private, the academic and market-oriented, the social and economic, the domestic and global are blended; making current educational discourse impossible to separate the ideologies shaping current initial teacher education. Education faculties have not let go of the old, but also in order to survive, have to find solutions regarding the existing pressures caused by internal and external forces, which are not static. In this impure combination, education faculties have responded by equipping prospective teachers with the knowledge and skills they need first as graduates, and secondly as professional teachers preparing to offer a public good function of education ${ }^{89}$ However, the second option still leaves a lot to

${ }^{88}$ Chris Yates, "Teacher education policy: International development discourse and the development of teacher education," 3.

${ }^{89}$ Christopher Lubienski, "Instrumentalist perspectives on the 'Public' in Public Education: Incentives and purposes." 
be desired, since it is a costly venture for public universities, which are under-funded, and for private universities, which are for-profit and less focussed on the professional development of prospective teachers. Consequently, universities are bogged down in a predicament of simultaneously meeting professional, academic and market demands. These impure combinations conflicting with each other necessitate further interrogation and intervention.

The East African States should cascade the regional qualifications framework once it is approved taking into consideration country-specific needs, as well as develop national initial teacher education frameworks to guide the development and review of initial teacher education curricula. Underlying this development is the need to repackage existing initial teacher education curricula to embrace holistic practice-based competences where content is integrated with formative assessment and school-based training is blended with university-based training as the case is in South Africa and in England and Wales. ${ }^{90}$ More specifically, teacher education faculties could consider a number of characteristics in the development of their curricula which include futuristic nature of teacher education programmes, welldefined set of professional standards, carefully designed rigorous curriculum, strong relationships and partnerships with local schools, comprehensive and continuous assessment of learning outcomes, theory coupled with practice, rigorous entrance process for the students, problem-based methods of learning, appropriately extended field experiences, alignment with the structure and organisation of the school system, collaboration with all important stakeholders, deliberate and thoughtful conceptual framework, and continuous professional development and support for faculty members. ${ }^{91}$ The $21^{\text {st }}$ Century skills such as critical and analytical thinking, problem-solving, creativity, effective communication, leadership, ITC literacy, environmental and conservation literacy, global and multicultural literacy, economic literacy and health and wellness literacy should be integrated into the initial teacher education curricula.

Further, in their staff development policies, universities could consider developing and rolling-out mandatory competence-based pedagogical courses for all teaching staff aimed at improving the quality of delivery of initial teacher education curricula.

90 Janet S. Stuart and Maria Teresa Tatto, "Designs for initial teacher preparation programs: An international review," 33.

${ }^{91}$ Muhammad Dilshad and Hafiz M. Iqbal, ““'Quality indicators in teacher education programmes," 404, citing National Association for State Boards of Education (2000); Scannell (2002); Sultana (2007). 


\section{Bibliography}

Altbach, Phillip, G. "Comparative Perspectives on Private higher education." In Private Prometheus: Private Higher Education and Development in the $21^{\text {st }}$ Century, edited by Phillip, G. Altbach. West Port: Greenword Press, 1999.

Avalos Beatrice, "Teacher education in the Latin American region: an unfinished business," Southern African Review of Education, A Journal of Comparative Education and History of Education 14, nos. 1-2; 9-27 (2008).

Bamanyaki K. Yoweri. "Teacher education programmes and teacher effectiveness in Uganda."A Unpublished M.Ed. Dissertation of Makerere University, Kampala, 1979.

Bongoko N. Sorobea. A history of modern education in Kenya (1895-1991). Nairobi: Evans Brothers Kenya Ltd., 1992.

Buchberger Friedrich, Bártolo P Campos, Daniel Kallos, and John Stephenson, eds. "Green paper on teacher education in Europe: High quality teacher education for high quality education and training." Thematic Network for Teacher Education in Europe (TNTEE): Umea University, Sweden, 2000), retrieved on 13.4. 2008 from http://tntee.umu.se/publications/greenpaper/greenpaper.pdf.

Busingye Bonny. "Teacher education in the School of Education at Makerere University." An Unpublished M.Ed. Dissertation in Teacher Education, University of Manchester, 1989.

Carnoy Martin. "Lessons from the past two decades: investment choices for education and growth." Southern African Review of Education. A Journal of Comparative Education and History of Education 13, no. 2 (2007): 5-26.

Carrol Bidemi. "Harnessing private monies to fuel university growth." Southern African Review of Education. A Journal of Comparative Education and History of Education 13, no. 2 (2007): 77-92.

DIES 111. " 3 rd Dialogue on Innovative Higher Education Strategies, Conference Documentation on Quality Assurance through Curriculum Design: A Case Study of Higher Education Management in East Africa." DAAD, HRK, IUCEA, JKUAT, Nairobi, Kenya, October $9^{\text {th }}-11^{\text {th }}, 2003$.

Dilshad Muhammad and Iqbal M. Hafiz. "Quality indicators in teacher education programmes.” Pakistan Journal of Social Sciences 30, no. 2 (2010): 401-411.

ESAURP - Eastern \& South African Universities Research Program, University capacity in Eastern and Southern African Countries, (University of Dar es Salaam: James Carrey Ltd: London, 1987).

Feiman-Nemser Sharon. "From preparation to practice: Designing a continuum to strengthen and sustain teaching." Teachers' College Records 103 (2001): 1013-1055.

Furlong V. John, Hirst H. Paul, Keith Pocklington, and Johnstone S. Miles. Initial teacher training and the role of the school. Milton Keynes: Open University Press, 1988.

Gardner Roy, "Contemporary crises in teacher education: an overview." In Contemporary crises in teacher education. Edited by Roy Gardner, 2-14. The 
British Association of Teachers and Researchers in Overseas Education, London: University of London, 1995.

Goodwin A. Lin. "Globalisation and the preparation of quality teachers: rethinking knowledge domains for teaching." Teaching Education 21, 1 (2010): 19-32. Retrieved from http://dx.doi.org/10.1080/10476210903466901 on 23rd May, 2014.

Herrmann Ulrich. "Universitäre Gymnasiallehrerausbildung: Die lange Geschichte einer Selbst-illusionierung und ein Plädoyer für eine Berufsfakultät." Pädagogische Rundschau Heft 5/Septemmber-Oktober 44 (2001): 565v - 684.

Woon Ye Ho, Judy. "Curriculum documents as representation of institutional ideology - A comparative study." Language and Education 16, $\mathrm{n}^{\circ} 4$ (2002).

Hulme, Moira, and Ian Mentor, "Learning to teach in post-devolution UK: A technical or an ethical process." Southern African Review of Education. A Journal of Comparative Education and History of Education 14, nos. 1-2 (2008): 43-64.

Inter-University Council for East Africa, Jumuiya ya Afrika Mashariki, East African Business Council, Regional higher education qualifications gaps versus the region's human resources needs: Finding EAC Higher Education Competence Sweet Spot, Situation composite EAC Report, Unpublished, Vol. II, (June, 2014).

Ishumi G. M. Abel. "The teaching profession and teacher education: Trends and Challenges in the 21st Century." Africa Education Review 10, 1 (2013): 89-116, retrieved on 24th Feburuary, 2014 from http://dx.doi.org/10.1080/18146627.20 13.855435

Kaberia, Festus, Mutinda M. Joyce, and Kobia K. Margaret. "Regulation and quality assurance mechanisms for transnational (Commercial) providers of higher education in Kenya." In (ed.) Higher Education: Cross-border higher education: regulation, quality assurance and impact. Vol. II. Edited by Michaela Martin. International Institute for Educational Planning, UNESCO, 2007.

Liang Xiaoyan. Uganda Tertiary Education Sector, Africa Region Human Resource Development. Working Paper Series, World Bank: Africa Region, 2004.

Lubienski, Christopher. "Instrumentalist perspectives on the 'Public' in Public Education: Incentives and purposes." Educational Policy 17, no. 4 (2003): 478502. Downloaded on Nov. 27 $7^{\text {th }}, 2013$ from http://epx.sagepub.com/cgi/content/ abstract/17/4/478

Lugumba, E. Samuel, and John C. Ssekamwa. A History of Education in East Africa (1900-1973). Kampala Bookshop Publishing Department, 1973.

Makerere University College of Education and External Studies Strategic Plan (2011/12-2018/19) (2011).

Nabudere, W. Daniel. "The development state in Africa." Southern African Review of Education. A Journal of Comparative Education and History of Education 13, no. 2 (2007):125-138.

NCHE - National Council for Higher Education. "State of Higher Education, A Report of a Survey of Uganda's Institutions of Higher Learning." NCHE: Kampala, 2012. 
. “Strategic Plan 2007-2011, No 11.” NCHE, Kampala, 2007.

."Graduate Tracer and Employers' Expectations Studies.” NCHE, Kampala, 2007.

—. "Quality Assurance Framework for Uganda Universities.” NCHE, Kampala, 2006.

- The State of Higher Education: A Report of a Survey of Uganda's Institutions of Higher Learning." NCHE, Kampala, 2004.

OECD. "Educating the educators." Background paper presented for the OECD International Seminar on Teacher Education Diversity, October, 2010.

Otunga N. Ruth. "A comparative study of Makerere University and Moi University Schools of Education." An unpublished study sponsored by the German Academic Exchange Service and administered through the Inter-University Council for East Africa, 2005.

Report of the Visitation Committee to Public Universities. Unpublished, 2007.

Republic of Kenya. "Development of Education in Kenya." Ministry of Education, Science \& Technology, Nairobi, Kenya, 2004.

Sankey Derek. "The problematic of pre-service teacher education and its possible resolution at Hong-Kong Institute of Education.” 2001. Retrieved on May 2008 from: www.ied.edu.hk/celts/symposium/doc-fullpapers/Sankey0706.doc

Schwille, John, and Dembélé Martial. Global perspectives on teacher learning: Improving policy and practice. Paris: UNESCO International Institute for Educational Planning, 2007.

Ssekamwa, C. John. History and Development of Education in Uganda. Kampala: Fountain Publishers, 1997.

Ssentamu N. Proscovia. "A comparison of Ugandan, English and German teacher education models." Southern African Review of Education. A Journal of Comparative Education and History of Education 14, nos. 1-2 (2008): 65-76.

- The theory-practice discourse in Initial Teacher Education: Perspectives, problems and opportunities. Bayreuth African Studies: Bayreuth University, Germany, 2006.

Stuart, S. Janet and Tatto Maria Teresa. "Designs for initial teacher preparation programs: An international review." International Journal of Educational Research 33 (2000): 493-514.

Sultana G. Ronald. "The initial education of high school teachers: a critical review of major issues and trends." Studying Teacher Education 1, 2 (2005): 225-243.

Teferra, Damtew, and Altbach G. Philip, "African higher education: Challenges for the 21st Century." Higher Education 47, 1(2004): 21-50.

UDSM. "Undergraduate programs and administration procedure." Office of the Deputy Vice Chancellor for Academic, Research and Consultancy, University of Dar es Salaam, 2007.

—. "Prospectus, 1990-1991." Research and Publications Section. Dar es Salaam: Dar es Salaam University Press, 1990).

Uganda Government. White Paper on Education. Kampala: Ministry of Education and Sports. Kampala, Uganda, 1992. 
UNESCO. Statistical Year Book. UNESCO, Paris, 1999.

UIS, UNESCO Institute of Statistics. Database Website, 2003.

Varghese N.V. Private Higher Education in Africa. Paris: UNESCO, 2004).

Webster, $3^{\text {rd }}$ New International Dictionary of the English Language Unabridged. Edited by Philip Babcock Gove and the Merrian-Webster. Cologne: Könemann, 1993.

Yates Chris. "Teacher education policy: International development discourse and the development of teacher education." Paper prepared for the Teacher Policy Forum for Sub-Saharan Africa. UNESCO: Paris, 6-9 November, 2007. Downloaded from http://unesdoc.unesco.org/images/0015/001557/155738e.pdf on 1st July, 2014. 